\title{
Assessment of Fertility Status of Soils under Different Cropping Patterns and Implications for Sustainable Agricultural Land Management
}

\author{
Olaniyi A.O. ${ }^{1}$, Gadah E \\ 1,2 Department of Environmental Management, \\ Faculty of Environmental Sciences, \\ Kaduna State University, \\ Kafanchan Campus, \\ Kaduna State.
}

Email: akeem.olaniyi@kasu.edu.ng

\begin{abstract}
Soil fertility assessment is essential for effective land management practices. Therefore, this study was conducted to assess the physico - chemical characteristics of soil under different (Ginger, Maize, Mango and Oil palm) cropping systems and to test for significant differences in the nutrient in order to provide basis for recommending site/crop specific land management practices in the study area. Soil samples under the aforementioned cropping systems were collected from three sites (Ungwan Rana, Kurmin Kwara and Kyari) in Daddu of Jaba Local Government Areas of Kaduna State at two (surface and subsurface) levels using soil auger. The samples collected were subjected to physico-chemical analyses at the Institute for Agricultural Research (IAR) Ahmadu Bello University Zaria. The results of the analyses showed that the $\mathrm{pH}$ of all the soils ranged between slightly acidic to slightly alkaline. Whereas the bulk densities, organic carbon, Nitrogen, Phosphorus and Potassium contents were between moderate to high range at the surface and subsurface levels. The soil porosity, moisture content and Cation Exchangeable Capacity were mostly high for soil under all the crops investigated at the surface and sub surface levels. Results of inferential statistics revealed that there are significant differences in the soil bulk density, moisture content, $p H$ and Phosphorus amongst the croplands and between the depths indicating the impact of agricultural practices on soil of the study area. This study therefore recommended the use of organic matter to remediate impending soil acidity under ginger and oil palm cultivation in the study area.
\end{abstract}

Keywords: Cropping systems; land management; soil fertility; statistical analyses; Sustainable productivity

\section{INTRODUCTION}

Soil is a weathered mantle of unconsolidated material covering the land surface, comprising of a mixture of mineral elements and organic matter providing anchorage (Khan, 2013), warmth and protection to plants (Doran \& Parkin, 1994); purification of water, detoxification of pollutants and cycling of Carbon, Boron, Phosphorus, Sulphur and water (Lal, 2001; Beverick and Arnold, 2012). Soil is a dynamic system within where series of changes occur (Songu et al., 2021). These changes directly affect the composition, properties 
and productivities of the soil (Oriola and Hammed, 2012). In some cases, spatio temporal variations in soil properties depict changes in geology (Burke, 2002; Koojman et al., 2005; Umeri et al., 2017); climatic change (Dexter \& Richard, 2009) and soil management practices (Amusan et al., 2006; Basaran et al., 2006; Gupta et al., 2009; Yakub, 2012; Ogunkunle, 2013; Loria et al., 2016). The physico - chemical properties ( $\mathrm{pH}$, soil texture, moisture, porosity, bulk density, soil organic carbon, organic matter, cation exchange capacity, total nitrogen, phosphorus and potassium) of soil affect nutrients' availability, biota growing conditions, and soil physico - chemical and biological properties (Yakub, 2012).

Previous studies on the influence of cropping systems on soil physico - chemical properties have indicated varied and conflicting results (Oladoye, 2015; Hacimuftuoglu and Oztaz, 2017; Oriola and Atiyong, 2020). For instance, study of Oladoye, 2015 on the physico chemical properties of soil of tropical secondary forest indicated significant variations in $\mathrm{Ca}^{2+}, \mathrm{K}^{+}, \mathrm{Mg}^{2+}, \mathrm{Na}^{+}, \mathrm{CEC}, \mathrm{OM}$ and $\mathrm{OC}$ but insignifcant variation in sand, clay and silt content. Whereas the studies of Ogunkunle 2013; Yahaya et al., 2014; Hacimuftuoglu \& Oztaz, 2017; Suleiman, et al., 2017; Rajesh et al., 2017; Oriola \& Atiyong, 2020 found differences in the properties of soils under different cropping systems. Whereas, Loria et al., 2016 found that the traditional cropping systems had no influence on the soil properties.

Given that soil fertility management is fundamentally important to achieving sustainable agricultural production (Abdulwahab et al., 2019). Increasing agricultural productivities become necessary given that global hunger affecting 815 million people had been predicted to have greatest impacts in Africa than in any other parts of the World (FAO, 2017); there is therefore a need for conservation of the natural resource base for increased agricultural productivities (FAO, 2017). This research is therefore conducted to assess whether there are significant differences in the nutrient status of soil under different cropping patterns with the aim of suggesting appropriate site specific and sustainable soil management practices.

\section{MATERIALS AND METHODS}

Study Area: The study area (Daddu) is located between latitude $9^{0} 18^{\prime} 50^{\prime \prime} \mathrm{N}$ to $9^{0} 36^{\prime} 46^{\prime \prime} \mathrm{N}$ and longitude $8^{0} 50^{\prime} 0^{\prime \prime} \mathrm{E}$ to $9^{0} 10^{\prime} 12^{\prime \prime} \mathrm{E}$. It is one of the districts in Jaba Local Government Area. Jaba Local Government Areas share boundaries with Zango Kataf in the North, Jema'a in the East, Kachia by the West, Kagarko Local Government area and Nassarawa state by the South.

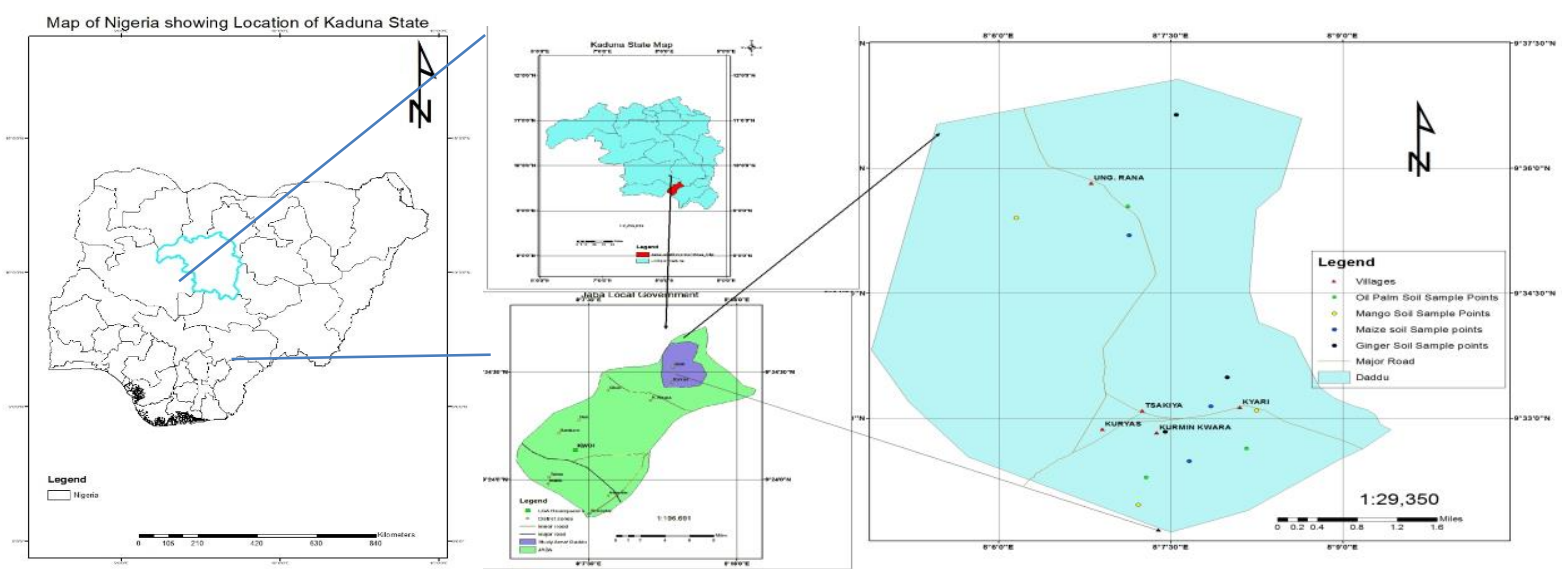

Fig. 1. Location of the Study Area with Sampling Points Source: Author, 2021 
The climate of the study area is characterized by two distinct seasons with annual average annual rainfall ranging between $1000 \mathrm{~m}$ and $1500 \mathrm{~m}$ (Abaje et al., 2015) and temperature ranges between $27{ }^{\circ} \mathrm{C}$ and $30^{\circ} \mathrm{C}$ (Danladi et al. 2017) and mean relative humidity 63\% (Abaje et al. 2015). Soil of study area is predominantly sandy loam of tropical ferruginous soils (Abaje et al. 2010) suitable for cultivation of sorghum, millet, maize, yam, rice, cocoyam, groundnut, acha, beans, ginger, cassava, soya bean, sweet potatoes, benniseed and sugar cane, vegetables such as cabbage, spinach, tomatoes and pepper (Eroarome, 2009). Jaba local government is made up of thirteen districts (Anamayi and Anamayi, 2018) with population of 61,000 (Danladi et. al., 2017) with residents mostly engaged in farming and other non farm to secure households financial needs (Danladi et al., 2017).

\section{Sample Collection}

Reconnaissance survey was conducted between 8th - 10th October, 2020. Core samples were collected using soil auger at three different sampling points within a square quadrat of $20 \mathrm{~m}$ by $20 \mathrm{~m}$ with two composite samples from surface and subsurface having the depths of 0 $30 \mathrm{~cm}$ and $30-60 \mathrm{~cm}$ respectively for permanent (Oil palm and Mango) crops and depths of 0 - $15 \mathrm{~cm}$ and $15-30 \mathrm{~cm}$ for surface and subsurface respectively for annual (Ginger and Maize) crops from three (Ungwan Rana; Kurmin Kwara and Kyari) communities (Table 1).

Table 1: Sampling Locations

\begin{tabular}{|c|c|c|c|}
\hline \multicolumn{4}{|c|}{ Ungwan Rana } \\
\hline Crops & Latitude & Longitude & Height \\
\hline Mango & $9035^{121.0711 N}$ & $8^{0} 6^{109} .68^{11} \mathrm{E}$ & $746.20 \mathrm{~m}$ \\
\hline Oil Palm & $9035^{136.10^{11} \mathrm{~N}}$ & $8^{007108.66^{11} \mathrm{E}}$ & $759.56 \mathrm{~m}$ \\
\hline Ginger & $9036^{128.73^{11} \mathrm{~N}}$ & 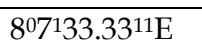 & $759.50 \mathrm{~m}$ \\
\hline Maize & $9035^{133.78^{11} \mathrm{~N}}$ & $8^{007108.94^{11} \mathrm{E}}$ & $758.34 \mathrm{~m}$ \\
\hline
\end{tabular}

\begin{tabular}{|l|l|l|l|}
\hline Kurmin Kwara & Latitude & Longitude & Height \\
\hline Crops & $9^{032^{1} 47.95^{11} \mathrm{~N}}$ & $8^{0} 07134.60^{11} \mathrm{E}$ & $759.87 \mathrm{~m}$ \\
\hline Mango & $9^{0} 32^{1} 10.48^{11} \mathrm{~N}$ & $8^{071} 12.87^{11} \mathrm{E}$ & $752.50 \mathrm{~m}$ \\
\hline Oil Palm & $9^{03} 2^{135.0111} \mathrm{~N}$ & $8^{071} 19.67^{11} \mathrm{E}$ & $755.29 \mathrm{~m}$ \\
\hline Ginger & $9^{0} 32^{147.78^{11} \mathrm{~N}}$ & $8^{0} 07126.72^{11} \mathrm{E}$ & $762 \mathrm{~m}$ \\
\hline Maize &
\end{tabular}

\begin{tabular}{|l|l|l|l|}
\hline Kyari & Latitude & Long. & Height \\
\hline Crops & $9^{0} 33^{14} .41^{11} \mathrm{~N}$ & $8^{0} 08^{11} 15.27^{11} \mathrm{E}$ & $752 \mathrm{~m}$ \\
\hline Mango & $9^{0} 33^{1} 01.15^{11} \mathrm{~N}$ & $8^{0} 08^{11} 15.59^{11} \mathrm{E}$ & $758.95 \mathrm{~m}$ \\
\hline Oil Palm & $9^{0} 33^{1} 0.99^{11} \mathrm{~N}$ & $8^{0} 08^{17} .01^{11} \mathrm{E}$ & $758.65 \mathrm{~m}$ \\
\hline Ginger & $9^{0} 33^{1} 10.41^{11} \mathrm{~N}$ & $8^{0} 08^{19} .1711 \mathrm{E}$ & 764.44 \\
\hline Maize &
\end{tabular}

Source: Authors, 2021

Samples were well labeled and then transported to the Institute for Agricultural Research (IAR) Ahmadu Bello University Zaria (ABU, Zaria) for the laboratory analyses. The samples were air - dried at room temperature, crushed and passed through a $2 \mathrm{~mm}$ sieve for the determination of physio - chemical characteristics of the soil samples. The particle size distribution was determined by Bouycouos hydrometeric method using sodium hexametaphosphate as a dispersant (Tel and Hagarthy, 1984). The textural classes were determined with the aid of USDA textural triangle. Bulk density was determined by the methodology described by Grossman and Reinsch, 2002 (Eqn. 1)

Bulk density $(\mathrm{g} / \mathrm{cm} 3)=\frac{\text { weight of oven dry soil }(g)}{\text { Volume }}$ 
Gravimetric moisture content was determined by comparing the weight of the field wet soil $(\mathrm{Wt})$ with the oven - dried soil $(\mathrm{Wd})$ for about 24 hours at $105^{\circ} \mathrm{C}$. The water content was calculated using Equation 2:

Gravimetric moisture content $=\theta d=\left(\frac{W t-W d}{W d}\right) \times 100$ (eqn 2)

Soil porosity was computed from bulk density and particle density using a formula

Total Porosity $=1$ - Bulk Density/Particle Density assuming a Particle Density of $2.65 \mathrm{mg} / \mathrm{m}^{3}$

Soil $\mathrm{pH}$ was measured in water and calcium chloride $\left.(0.01 \mathrm{M} \mathrm{CaCl})_{2}\right)$ using a glass - calomel combined with electrode after equilibrating for 30 minutes.

Organic carbon was determined using method described by Walkey and Black (Nelson and Sommers, 1996) (Eqn. 3).

$$
\% \text { OC }=\frac{(\text { blank }- \text { titre }) \times 0.3 \times m \times f}{\text { weight of soil }}
$$

where: $\mathrm{f}=$ corrected factor $(1.33) . \mathrm{m}=$ concentration of $\mathrm{FeSO}_{4}$.

Total Nitrogen was determined using Kjeldahl digestion method (Eqn. 4).

Percentage Nitrogen content in the soil was calculated thus:

$$
\% N=\frac{(g m s) \text { Nitrogen }}{(g m s) \text { Sample }} \times 100
$$

Available Phosphorus (P) - Total available phosphorus was determined using Bray II method (Olsen and Sommers, 1982). Potassium was determined using flame photometer after the photometer had been standardized with blank solutions. Cation exchange capacities were estimated tritometrically by distillation of ammonium that was displaced by sodium from $\mathrm{NaCl}$ solution. Organic matter was determined using Walkey Black Wet Oxidation method. Inferential (one - way ANOVA) statistics was used to test for significance differences in the soil physico - chemical parameters under different cropping systems at 95\% confident level.

\section{RESULTS AND DISCUSSION}

The tables showed the summary the results of the laboratory analyses conducted on the soil samples for the crop farms under investigation and at the surface (Table 2) and the subsurface levels (Table 3). 
Table 1: Physico - Chemical Parameters of Soil under Different Cropping Systems at Surface Level

\begin{tabular}{|l|l|l|l|l|}
\hline Level (Surface) & \multicolumn{2}{|c|}{ 0 - 15 } & \multicolumn{2}{c|}{ 0 - 30 } \\
\hline Crops & Ginger & Maize & Oil Palm & Mango \\
\hline Parameters & Mean \pm Std & Mean \pm Std & Mean \pm Std & Mean \pm Std \\
\hline Bulk Density & $1.52(0.17)$ & $1.46(0.24)$ & $1.26(0.16)$ & $1.08(0.05)$ \\
\hline Soil Porosity & $15.31(6.33)$ & $20.44(2.24)$ & $13.54(4.18)$ & $15.31(11.38)$ \\
\hline Moisture Content & $3.47(1.81)$ & $4.13(4.25)$ & $1.27(0.34)$ & $2.22(0.40)$ \\
\hline pH $\left(\mathrm{H}_{2} \mathrm{O}\right)$ & $6.40(0.92)$ & $7.60(0.10)$ & $6.73(1.33)$ & $7.431(0.06)$ \\
\hline pH $\left(\mathrm{Cacl}_{2}\right)$ & $5.60(0.82)$ & $6.80(0.10)$ & $5.93(1.24)$ & $6.70(0.10)$ \\
\hline Organic Carbon & $1.42(0.40)$ & $1.34(0.27)$ & $1.24(0.30)$ & $1.19(0.31)$ \\
\hline Organic Matter & $2.45(0.70)$ & $2.30(0.47)$ & $2.14(0.52)$ & $2.06(0.53)$ \\
\hline Nitrogen & $0.31(0.09)$ & $0.29(0.06)$ & $0.27(0.07)$ & $0.26(0.07)$ \\
\hline Phosphorus & $27.67(21.34)$ & $10.58(3.64)$ & $12.91(8.08)$ & $4.63(0.86)$ \\
\hline Potassium & $0.35(0.14)$ & $0.19(0.04)$ & $1.03(1.41)$ & $0.52(0.22)$ \\
\hline ECEC & $16.04(6.51)$ & $14.06(3.37)$ & $19.53(11.34)$ & $16.07(2.69)$ \\
\hline Clay & $4.67(1.15)$ & $6.67(1.15)$ & $6.67(3.06)$ & $6.67(3.06)$ \\
\hline Silt & $11.67(3.21)$ & $14.00(1.00)$ & $16.00(4.36)$ & $14.67(4.51)$ \\
\hline Sand & $83.67(3.79)$ & $79.33(1.53)$ & $77.33(7.23)$ & $73.67(7.51)$ \\
\hline
\end{tabular}

Table 2: Physico - Chemical Parameters of Soil under Different Cropping Systems at Subsurface Level

\begin{tabular}{|l|l|l|l|l|}
\hline Level (Subsurface) & \multicolumn{2}{|c|}{$16-30$} & & \multicolumn{2}{c|}{31 - 60 } \\
\hline Crops & Ginger & Maize & Oil Palm & Mango \\
\hline Parameters & Mean \pm Std & Mean \pm Std & Mean \pm Std & Mean \pm Std \\
\hline Bulk Density & $1.49(0.15)$ & $1.43(0.07)$ & $1.19(0.02)$ & $1.11(0.08)$ \\
\hline Soil Porosity & $29.22(15.98)$ & $12.29(7.58)$ & $11.7(5.39)$ & $19.45(6.83)$ \\
\hline Moisture Content & $2.22(0.54)$ & $4.76(2.18)$ & $1.56(0.31)$ & $2.19(1.07)$ \\
\hline $\mathrm{pH}\left(\mathrm{H}_{2} \mathrm{O}\right)$ & $6.73(1.16)$ & $7.83(0.12)$ & $6.80(1.57)$ & $7.40(0.10)$ \\
\hline $\mathrm{pH}\left(\mathrm{Cacl}_{2}\right)$ & $5.70(1.10)$ & $6.87(0.12)$ & $5.87(1.50)$ & $6.70(0.10)$ \\
\hline Organic Carbon & $0.91(0.46)$ & $1.04(0.15)$ & $0.66(0.17)$ & $0.72(0.10)$ \\
\hline Organic Matter & $1.57(0.80)$ & $1.50(0.25)$ & $1.13(0.29)$ & $1.25(0.17)$ \\
\hline Nitrogen & $0.20(0.10)$ & $0.22(0.04)$ & $0.14(0.04)$ & $0.16(0.02)$ \\
\hline Phosphorus & $19.38(19.75)$ & $6.12(1.80)$ & $4.46(0.45)$ & $4.00(1.59)$ \\
\hline Potassium & $0.30(0.14)$ & $0.17(0.02)$ & $0.57(0.75)$ & $0.23(0.15)$ \\
\hline ECEC & $13.72(5.52)$ & $9.91(1.20)$ & $14.01(6.95)$ & $10.21(1.44)$ \\
\hline Clay & $5.33(2.31)$ & $8.67(1.15)$ & $8.67(1.15)$ & $10.00(2.00)$ \\
\hline Silt & $15.33(3.06)$ & $17.67(2.52)$ & $17.67(3.21)$ & $19.67(3.51)$ \\
\hline Sand & $79.33(4.16)$ & $73.67(1.53)$ & $73.67(3.79)$ & $70.33(4.93)$ \\
\hline
\end{tabular}

The mean bulk density is highest in Ginger farm with $1.52 \mathrm{gcm}^{-3}$ and $1.49 \mathrm{gcm}^{-3}$ at the surface and subsurface respectively followed by Maize farm with $1.46 \mathrm{gcm}^{-3}$ and $1.43 \mathrm{gcm}^{-3}$. For Mango and Oil palm, the bulk densities are 1.08, 1.11 and 1.26, 1.19 for the surface and the subsurface respectively (Fig. 2). The lowest bulk density was observed in Mango and there is inverse relationship between bulk density and depth. 


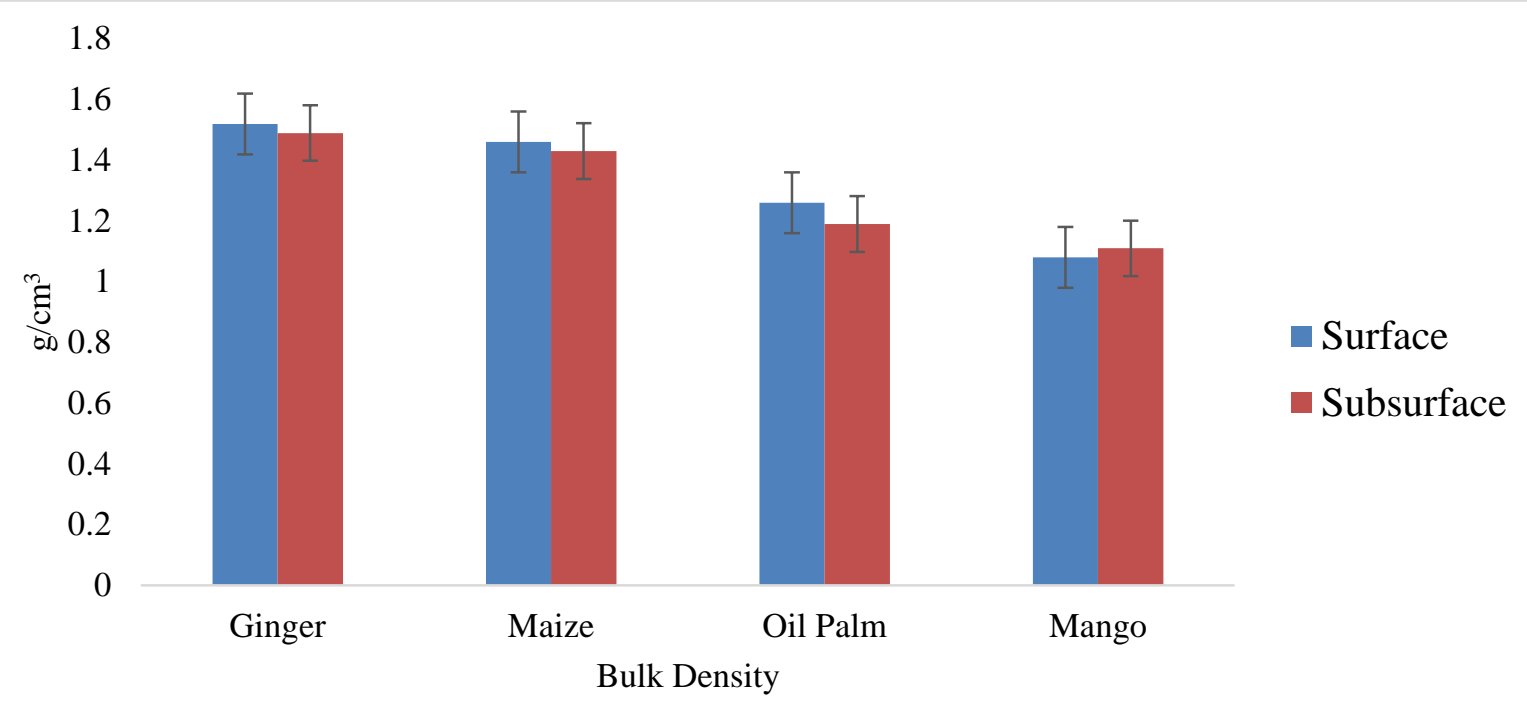

Fig. 2: Mean Bulk Density of Soil under different Cropping Systems

The soil $\mathrm{pH}$ was determined for $\mathrm{H}_{2} \mathrm{O}$ and $\mathrm{CaCl}_{2}$ at the surface and the subsurface levels for all the crop farms investigated. The result indicated a general increase in soil $\mathrm{pH}$ value with depth (Fig. 3) with highest values observed on Maize plot with average value of 7.60 and 7.83 under $\mathrm{H}_{2} \mathrm{O}$ and 6.80 and 6.87 under $\mathrm{CaCl}_{2}$ respectively for the surface and subsurface soil levels. Whereas, lowest values were recorded on Ginger farms with values of 6.40 and 6.73 under $\mathrm{H}_{2} \mathrm{O}$ and 5.60 and 5.70 under $\mathrm{CaCl}_{2}$. Increase in soil $\mathrm{pH}$ in all the croplands investigated particularly with depth might be due to leaching of exchangeable cations (Magaji et al., 2019) and reduction of organic matter with depth (Oladoye, 2015).
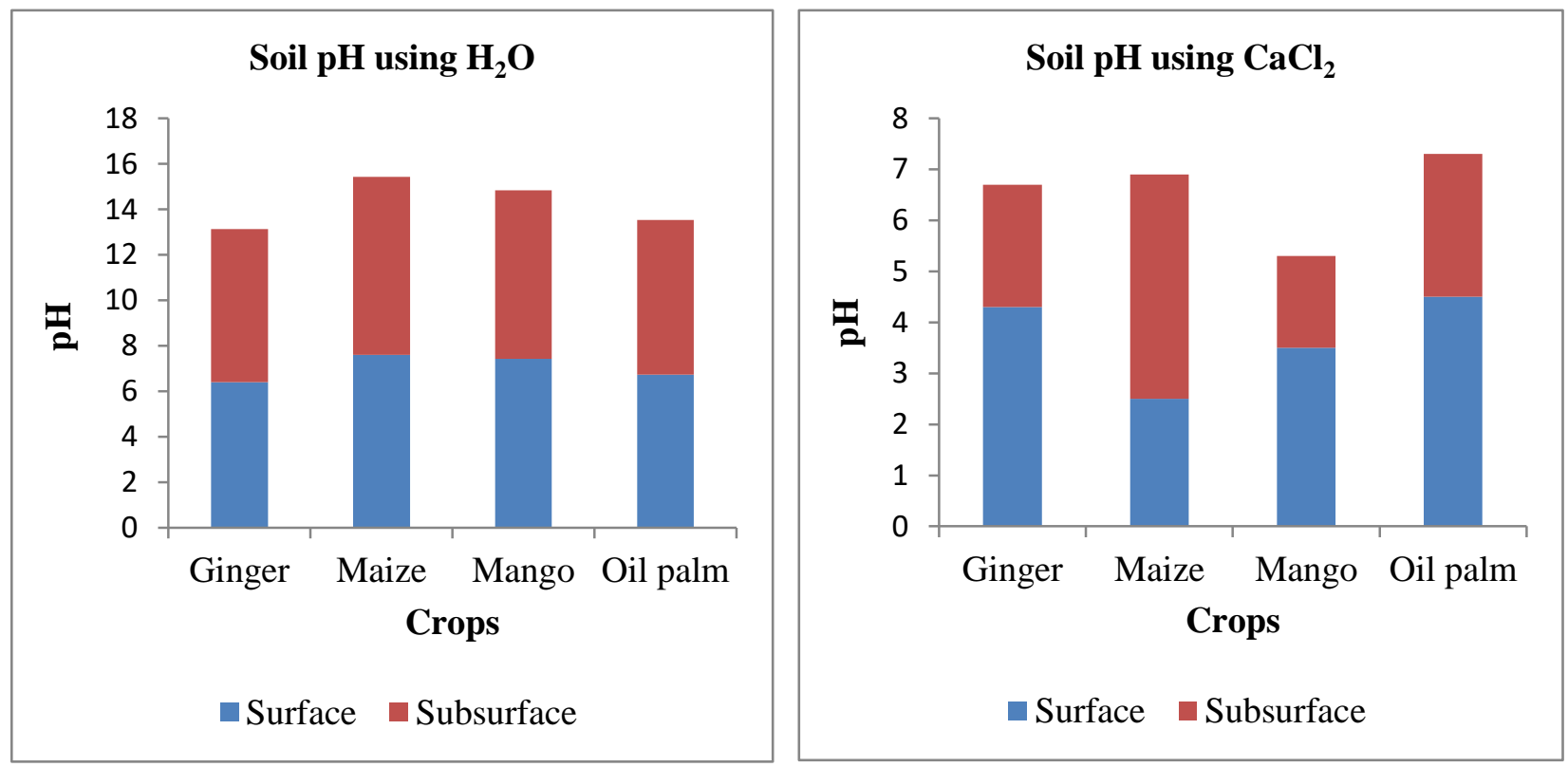

Fig. 3: Mean Soil pH under different Cropping Systems

For all the croplands investigated there were decrease in organic carbon with depth. Although, the values for the subsurface Organic Carbon fall within the moderate $(0.48 \%$ and $1.15 \%)$ range (Umeri et al., 2017), For instance, the results for the surface and subsurface organic carbon are Ginger (1.42\% and $0.91 \%)$, Maize $(1.34 \%$ and $1.04 \%)$, Mango $(1.19 \%$ and 
$0.72 \%)$ as well as Oil palm (1.24\% and $0.66 \%)$, (Tables 2 - 3 above and Fig. 4). The high Organic Carbon content most especially at the surface soil level may be due to the accumulation of organic matter over years (Ogeh and Osiomwan, 2012; Loria et al, 2016) and low mineralization (Osujeike et al, 2017).

The results for Organic Matter showed an inverse relationship with increasing soil depth. For example: values $2.45 \%$ and $1.57 \% ; 2.30 \%$ and $1.50 \% ; 2.06 \%$ and $1.25 \%$ and $2.14 \%$ and $1.13 \%$ were obtained for Ginger, Maize, Mango and Oil palm at the surface and the sub surface levels respectively, (Tables 2 - 3 and Fig4). These observed values were within moderate $(1.7 \%-2.6 \%)$ range described by (Oriola and Atiyong, 2020). The high level of Organic Matter in the surface soil could be due to the humus formed by fallen leaves (Yahaya, et al., 2014). Highest level of Organic Matter recorded on Ginger farm could be due to the use of organic manure by the farmers in the study areas.

Highest values $(0.31 \%$ and $0.21 \%)$ of Nitrogen was obtained from Ginger farm in the study area at the surface and subsurface soil levels. Whereas, lowest values of Nitrogen were recorded in Mango farm (0.26 and 0.16) The highest values recorded in the Ginger farm might not be unconnected with the use of Organic Matter by the farmers in the study area. (Tables 2 - 3 and Fig. 4).
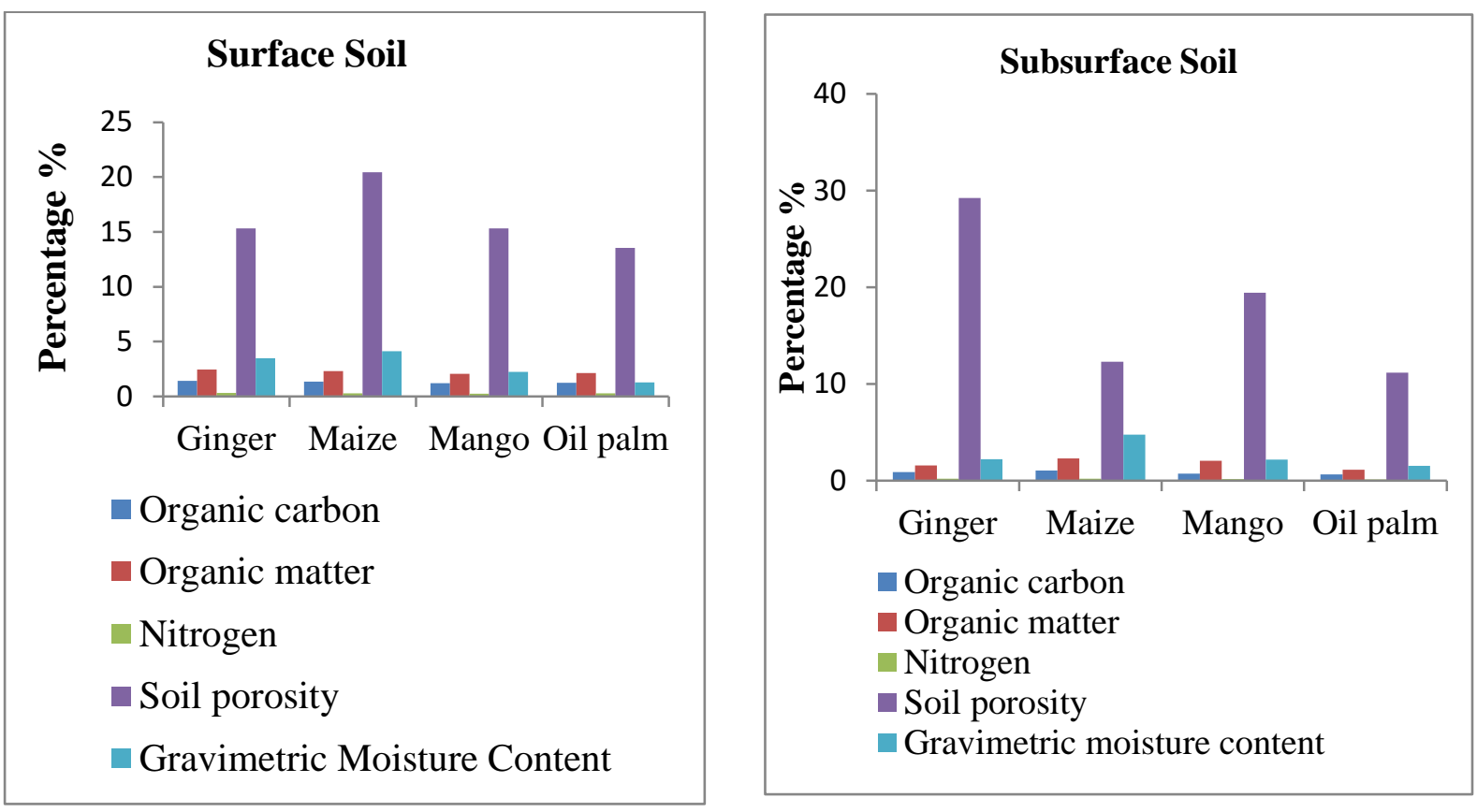

Fig. 4: Physico - Chemical Characteristics of Soils under different Cropping Systems

Soil Porosity were observed to be increasing from surface to subsurface in Ginger and Mango farms ie $15.31 \%$ to $29.31 \%$ and $15.31 \%$ to $19.45 \%$ respectively but decreasing with increasing soil depths in Maize and Oil palm farms $20.44 \%$ to $12.29 \%$ and $13.54 \%$ to $11.17 \%$ respectively (Tables 2 - 3 and Fig 4). For Ginger and Mango farms, there is an inverse relationship between soil porosity and soil depth (i.e the higher the soil depth the lower the soil porosity). Whereas, there is an observed higher soil porosity with increasing the soil depth. The higher soil porosity with increasing soil depth on Maize and Oil palm can be as a result of shallow root system of Maize and Oil palm compared to Ginger and Mango.

The results for Moisture Content in all the crops investigated and at the surface and 
subsurface soil levels are as follow 3.47 and 2.22; 2.22 and 2.19; 4.13 and 4.76 and 1.27 and 1.56 for Ginger, Mango, Maize and Oil palm farms respectively (Tables 2 - 3 and Fig. 4). The results indicated increase in soil Moisture Content with increasing soil depth on Maize and Oil palm farms, ie $4.13 \%$ and $4.76 \% ; 1.27 \%$ and $1.56 \%$. The increasing Moisture Content with soil depth on Maize and Oil palm farms is as a result of the drier soil condition due to lower Organic Matter and shallower root systems of Maize and Oil palm compared to the Ginger and Mango.

The following results were obtained for Available Phosphorus in the study area: $27.67 \mathrm{MgKg}$ 1 and $19.38 \mathrm{MgKg}^{-1}, 10.58 \mathrm{MgKg}^{-1}$ and $6.12 \mathrm{MgKg}^{-1}, 4.63 \mathrm{MgKg}^{-1}$ and $4 \mathrm{MgKg}^{-1}, 12.91 \mathrm{MgKg}^{-1}$ and $4.46 \mathrm{MgKg}^{-1}$ for Ginger, Maize, Mango and Oil palm with highest being on Ginger farm and lowest on Mango. The results also showed a decrease in Available Phosphorus with increasing depth thus agreeing with the findings of Oladoye, 2015.

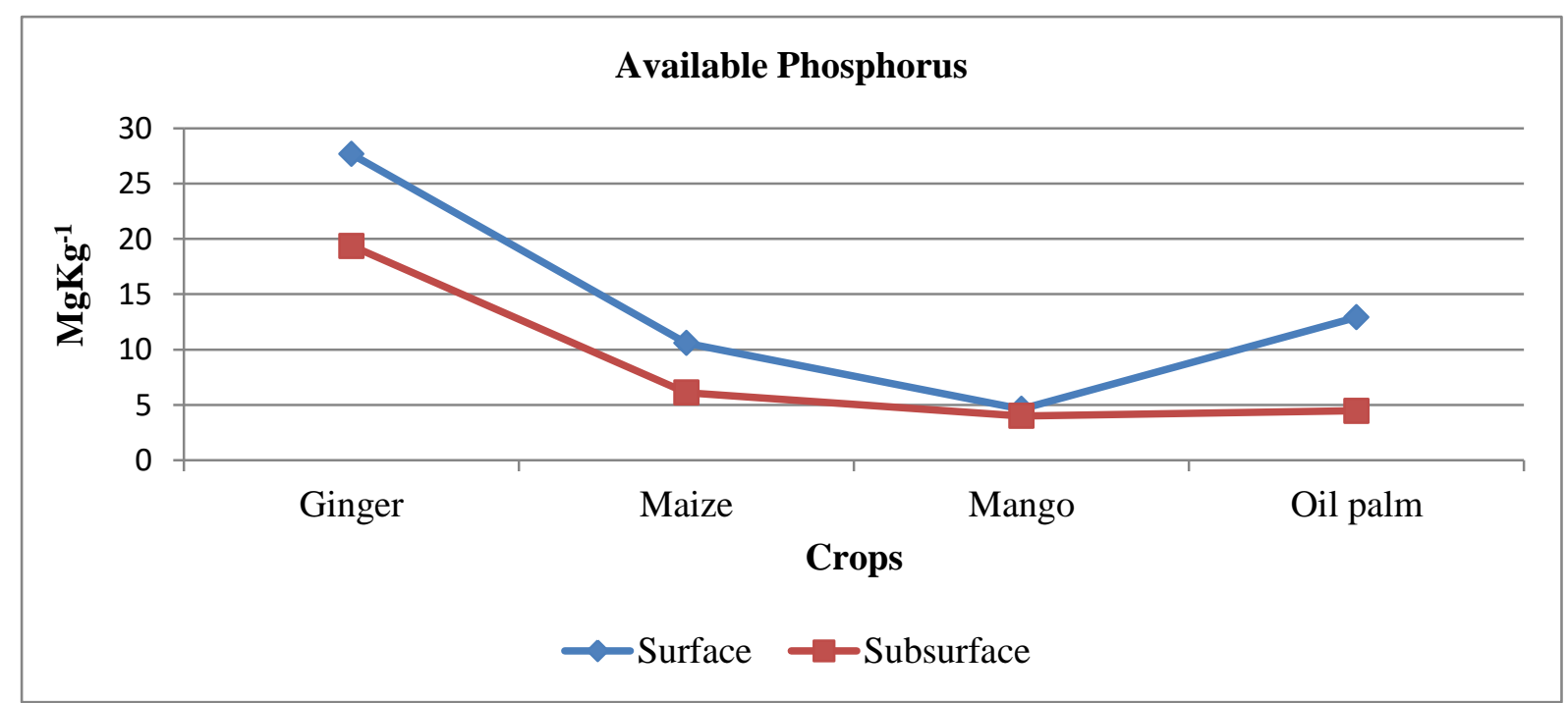

Fig. 5: Available Phosphorus in Soil under different Cropping Systems

The results of the laboratory analyses indicated that the Effective Cation Exchange Capacity was very high on Oil palm farm with $19.53 \mathrm{M}_{\mathrm{eq}} / 100 \mathrm{~g}$ and $14.01 \mathrm{M}_{\mathrm{eq}} / 100 \mathrm{~g}$ for surface and subsurface and low on Maize farm with $14.06 \mathrm{M}_{\mathrm{eq}} / 100 \mathrm{~g}$ and $9.92 \mathrm{M}_{\mathrm{eq}} / 100 \mathrm{~g}$ (Tables $2-3$ and Fig. 6). Ginger and Mango farms have $16.04 \mathrm{M}_{\mathrm{eq}} / 100 \mathrm{~g}$ and $13.72 \mathrm{M}_{\mathrm{eq}} / 100 \mathrm{~g}$ and 16.07 and $10.21 \mathrm{M}_{\mathrm{eq}} / 100 \mathrm{~g}$ at the surface and subsurface levels respectively (Tables 2 - 3 and Fig. 6). All the farms exhibited lower in ECEC at the subsurface level due lower Organic Matter content at the subsurface soil level (Oladoye, 2015) 


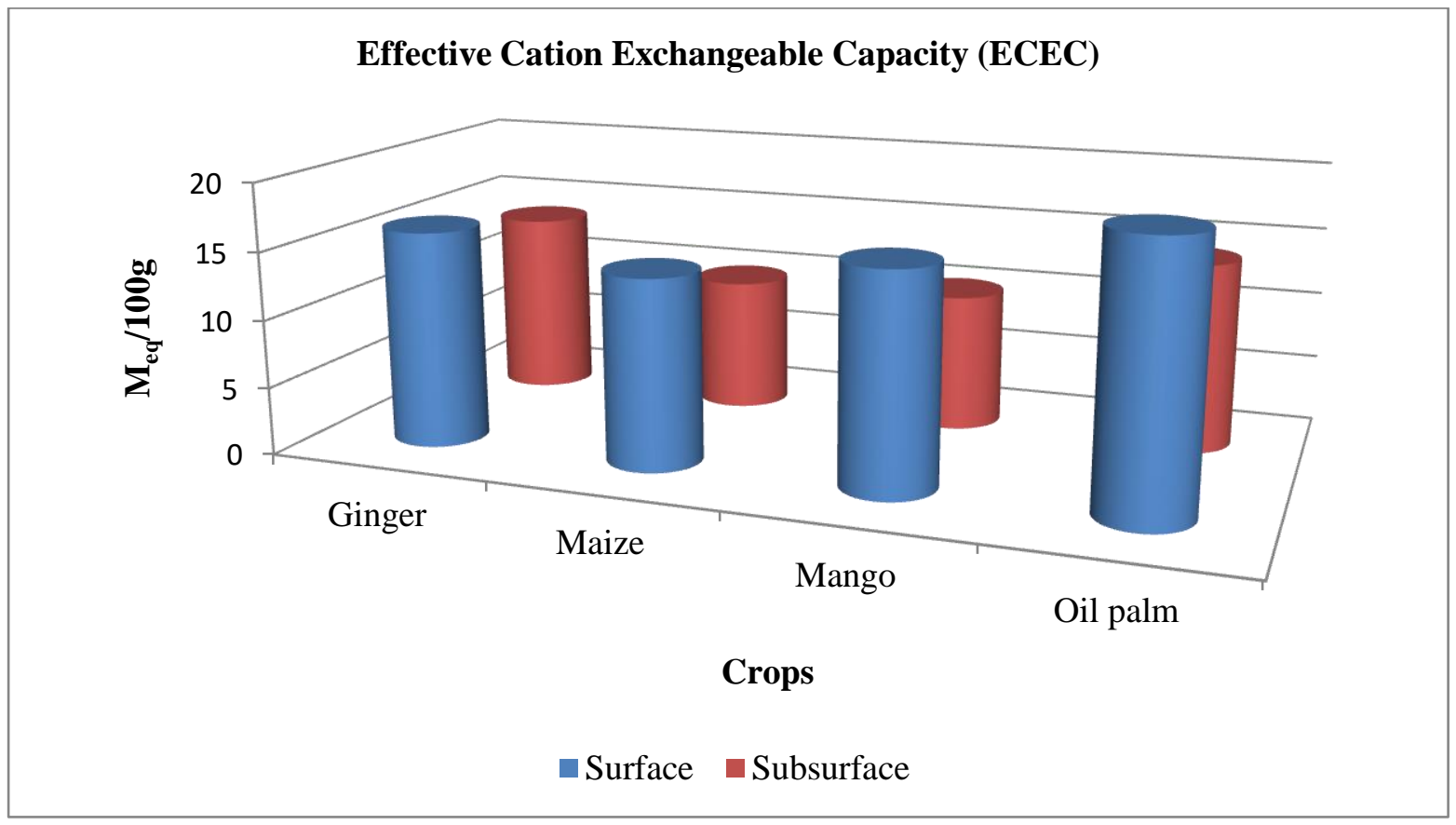

Fig. 6: Mean Effective Cation Exchange Capacity (ECEC)

Potassium showed decrease in concentration with increasing depth. The concentration of Potassium in Ginger, Maize, Mango and Oil palm from the surface and the subsurface were $0.35 \mathrm{M}_{\mathrm{eq}} / 100 \mathrm{~g}$ and $0.30 \mathrm{M}_{\mathrm{eq}} / 100 \mathrm{~g} ; 0.19 \mathrm{M}_{\mathrm{eq}} / 100 \mathrm{~g}$ and $0.17 \mathrm{M}_{\mathrm{eq}} / 100 \mathrm{~g} ; 0.52 \mathrm{M}_{\mathrm{eq}} / 100 \mathrm{~g}$ and $0.23 \mathrm{M}_{\mathrm{eq}} / 100 \mathrm{~g} ; 1.03 \mathrm{M}_{\mathrm{eq}} / 100 \mathrm{~g}$ and $0.57 \mathrm{M}_{\mathrm{eq}} / 100 \mathrm{~g}$ respectively (Tables $2-3$ and Fig. 7). The highest Potassium concentration was recorded on Oil palm farms and the lowest on Maize farm. This similar trend was also observed for Organic Matter and Organic Carbon content in the soil.

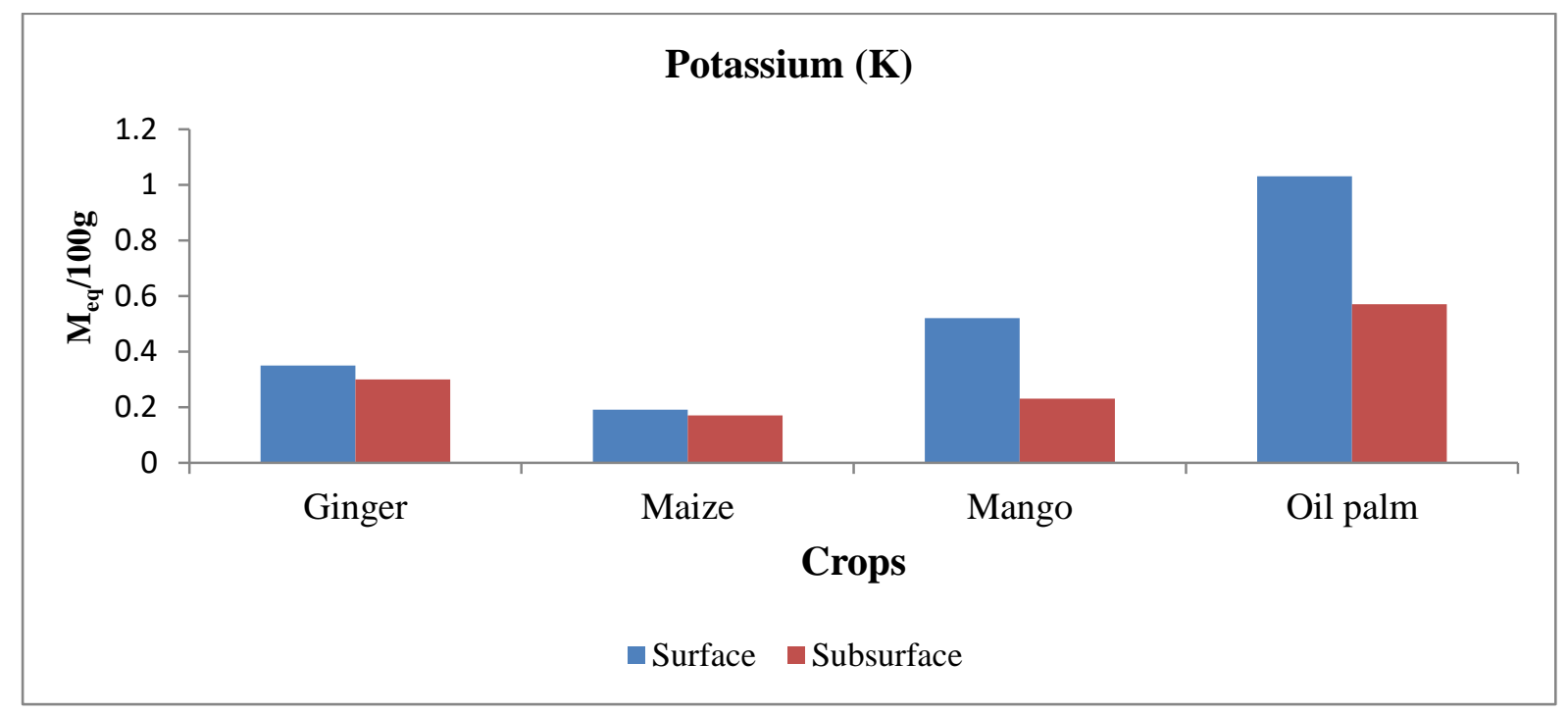

Fig. 7: Mean Concentration of Potassium in Soil under different Cropping Systems

Particle size distribution showed decreasing sand and silt with increasing depth except for clay that increased with increasing depth (Fig. 8) This finding agreed the findings of (Oladoye, 2015). 


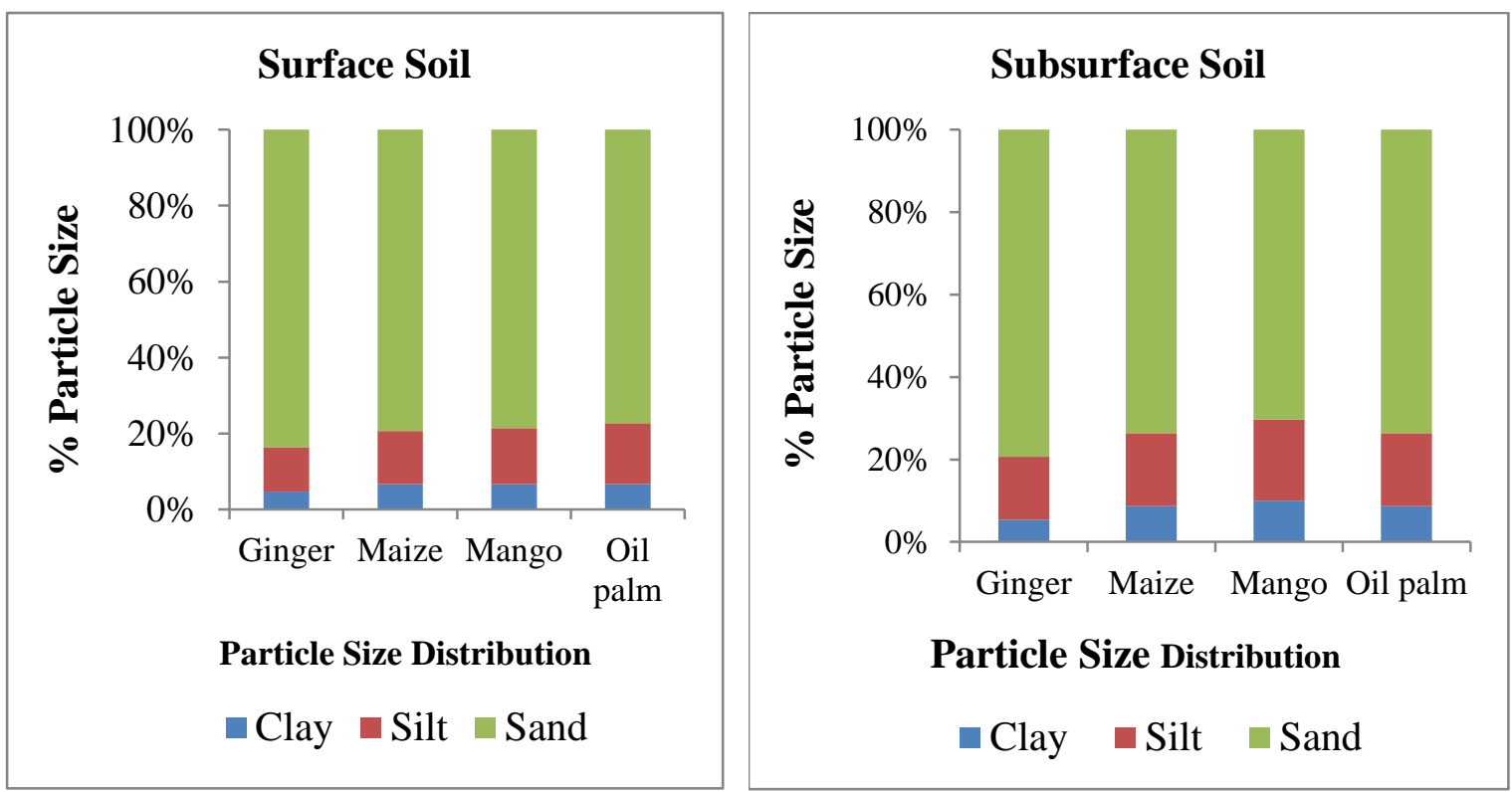

Fig. 8: Percentage (\%) Particles Size Distribution in Soil under different Cropping Systems

The results of the inferential analyses using Analysis of Variance (ANOVA) indicated that of all the 14 parameters investigated, only four parameters i.e Bulk Density, Moisture Content, $\mathrm{pH}\left(\mathrm{CaCl}_{2}\right)$ and Phosphorus were significantly different amongst all the crops at the three study areas. So also, only Organic Carbon, Organic Matter and Nitrogen were significantly different at the surface and subsurface soil levels. Bulk Density, Moisture Content and Clay proportion showed significant differences when soil under permanent crops were compared with soil under annual crops. There were significant differences in Bulk Density and Moisture Content when soil under Oil palm and Mango were compared and the statistical analysis showed significant differences in $\mathrm{pH}$ and Potassium when soils under Ginger was compared with those under Maize crops.

\section{CONCLUSION}

This study assessed the physico - chemical ( $\mathrm{pH}$, bulk density, available Nitrogen, Phosphorus, Potassium, effective cation exchange capacity, soil texture, organic matter, organic carbon and soil structure) parameters of soil under different (Ginger, Maize, Mango and Oil palm) cropping systems from three sites (Ungwan Rana, Kurmin Kwara and Kyari) at two (surface and subsurface) levels in Daddu of Jaba Local Government Areas of Kaduna State. Of all these parameters investigated, Bulk Density; Soil Moisture Content; $\mathrm{pH}\left(\mathrm{CaCl}_{2}\right)$ and Phosphorus were significantly different amongst all the crops. Implying that the agricultural practices in the study area mostly impact soil Bulk Density, Soil Moisture Content, $\mathrm{pH}\left(\mathrm{CaCl}_{2}\right)$ and Phosphorus. Therefore, future land management practices should be such that will not impact these parameters as the Bulk Density currently recorded is above the tolerant limit for most crops cultivated in the study area.

\section{REFERENCES}

Abaje, IB; Ishaya, S; Usman, SU (2010). Analysis of Rainfall Trends in Kafanchan, Kaduna State. Resource Journal of Environmental and Earth Sciences, 2(2): 89 - 96. 
Abaje, IB; Sawa, BA; Iguisi, EO; Ibrahim, AA (2015). Assessment of Rural Communities' Adaptive Capacity to Climate Change in Kaduna State, Nigeria. Journal of Environment and Earth Science, 5(20), 14 - 23.

Adamu, GK; Dawak, MU (2008). NPK level in Multiple Crop Land in a Smallholder Farm Land in Kano Closed Settled Zone. Biological and Environmental Sciences Journal for the Tropics, Bayero University Kano,, 5, 88 - 97.

Abdulwahab, I; Aliyu, J; Suleiman, R (2019). Evaluation of Soil Quality under Date Palm Plantation for Climate Change and Food Security in Gombe State University, Gombe Nigeria. Journal of Environmental Quality, 35, 51 - 64.

Amusan, A; Shitu, A; Makinde, W; Orewole, O (2006). Assessment of changes in selected soil properties under different land use in Obafemi Awolowo University Community, Ile-Ife, Nigeria. Electron J. Environl. Agric. Food Chem., 5, 1178 - 1184.

Anamayi SE; Anamayi, RM (2018). Resource use efficiency in Ginger production in Jaba Local Government Areas of Kaduna State, Journal of Humanities and Social Science 23(7): 14 21.

Bationo, A; Waswa, B; Kihara, J; Kimetu, J (2007). Advances in Integrated Soil Fertility Management in Sub-Saharan Africa. Challenges and Opportunities.

Beverick, E; Anold, R (2012). Is the Traditional Early Soil Knowledge and the Pedologic Definitio of Soil Meaningful in the Modern Context? Soil Horizons, 50(3).

Brady, NC; Weil, RR (1999). The Nature and Properties of Soils (12th ed. ed.). New Jersey: Prentice - Hall.

Brady, N; Weil, R (2007). The Nature and Properties of Soils (14th edition ed.). Prentice Hall, Upper Saddle River, New Jersey.

Burke, A (2002). Properties of soil pockets on arid Nama Karoo inselbergs-the effect of geology and derived landforms. J. Arid Environ., 50, 219 - 234.

Danladi, E; Akinola, MO; Banta, AL; Makarau, SB; Hussain A (2017). Socio - economic assessment of Ginger production in Jaba Local Government of Kaduna State, Nigeria. Asian Journal of Agricultural Extension, Economics and Sociology. 15(2): 1 - 11.

Dexter, A; Richard, S (2009). Soil structure: the key to soil function. . In a. s. Sustainable land management - environmental protection, P. M, \& J. R. (Eds.), Advances in GeoEcology 35: $57-69$.

Doran, J; Parkin, T (1994). Defining and assessing soil quality. In J. Doran, D. Coleman, D. Bezdizek, \& B. Steward, Defining soil quality for sustainable environment (pp. 1 - 24). Madison Wisconsin USA: SSSA Special Publisher No. 35.

Eroarome, MA (2009). Country Pasture/Forage Resource Profile Nigeria. Retrieved 1 16, 2021, from https:/ / www.scribd.com/document/346440160/FAO - Profile-Nigeria

Food and Agricultural Organisation. (2017). The State of Food Security and Nutrition in the World. Rome: FAO, IFAD, UNICEF, WEP AND WHO.

FAO, 2020. Crop production manual A guide to fruit and vegetable production in the Federated States of Micronesia FAO Subregional Office for the Pacific Food and Agriculture Organization of the United Nations Apia, 2020

Grossman, R: Reinsch, T (2002). Bulk density and linea extensibility,. In J. Dane, \& G. Topp, Methods of Soil analysis, Part 4. Physical methods. Soil Science Society of America Book series N0. 5 (pp. 201-228.). ASA and SSSA Madison, WI.2002.

Gupta, N; Kukal, SS; Bawa, SS; Dhaliwal, GS (2009). Soil organic carbon and aggregation under popular based agroforestry system in relation to tree age and soil type. Agroforestry Systems, 76, pp. 27 - 35.

Hacimuftuoglu, F; Ostaz, T (2017). Changes in Structural Parameters of Soils under Different Cropping Systems. Journal of the Agricultural Faculty, 48 (1), 9 - 15. 
Jafari, M; Sarmadian, F (2008). Fundamentals of Soil Sciences and Soil Classification ( Second Edition ed.). Tehran: Publications of University of Tehran.

Khan, T (2013). Soil Principle, properties and Management Springer. Dordrecht Heidelberg New York London .

Koojman, A; Jongejans, J; Sevink, J (2005). Parent material effects on Mediterranean woodland ecosystem in NE Spain. Catena, 59, pp. 55 - 68.

Lal, R (2001). Managing World Soils for Food Security and Environmental Quality. Advances in Agronomy, 74, pp. 155 - 192.

Loria, N; Bhardwaj, S; Ndugu, CK (2016). Impact of cropping systems on soils properties, nutrient availabilty and their carbon sequestration in Shiwalik hills of Himachal Pradesh. Journal of Applied and Natural Science, 8(3): 1479 - 1484.

Magaji, MJ; Samndi, AM; Gaya, AI (2019). Characteriztion and Classification of Soils in Kajuru Local Government Area of Kaduna State, pp. 1 - 15.

Nelson, DW; Sommers, LE (1996). Total carbon and soil organic matter. In: Methods of Soil Analysis. Part.3- Chemical Methods. Sparks, D.L. Page, A.L., Helmke, P.A., Loeppert, R.H., Soltanpour, P.N., Tabatabai, M.A., Johnston, C.T., Sumner, M.E. (Eds.). ASASSSA, Madison, Wisconsin, USA. pp. 961-1010.Nisar, N., \& Lone, F. (2013). Effect of land use / land cover change on soils of Kashmir Himalayan catchment. Journal of Research on Earth and Environmental Sciences, 1(1), 13-27.

Ogeh, J; Osiomwan, G (2012). Evaluation of the Oil Palm on Some Physical and Chemical Properties of Rhodic Paleudults. Nigeria Jornal of Basic and Applied, 20(1): 78-82.

Ogunkunle, O (2013). A Comparative Study of the Physical and Chemical Properties of Soils Under Different Vegetation Types. Journal of Environmental and Earth Science, 3(1): 24 28.

Oladoye , AO (2015). Physiochemical Properties of Soil Under Two Different Depths In a Tropical Forest of International Institute of Tropical Agriculture, Ibadan, Nigeria. Journal Of Research in Forestry, Wildlife And Environmental 7(1): 41 - 54.

Olsen, SR; Sommers, LE (1982). Available Phosphorus: In DL, Sparks AL, Page, PA, Helmke, RH Loeppert PN, Soltanpour, MA, Tabatabai, CT, Johnston and ME Sumner, (eds) Methods of Soil Analysis Part 3, Chemical Methods. Soil Science Society of America.

Oriola, EO; Atiyong, BR (2020). Soil Fertilty Under Different Farmland Management Practices for Sustainable Crop Production in Southern Kaduna, Nigeria. Sri Lanka Journal of Agricultural and Ecosystems, 2(1): 107 - 123.

Oriola, EO; Harmed, AT (2012). The Influence of Cattle Wastes on Degraded Savanna Soils of Kwara State Nigeria. Ethiopian Journal of Environmental Studies and Management, 2(1): 268 - 275.

Osujieke, DN; Imadojemu, PE; Ndukwe, BN; Okeke, OM (2017). Properties of Soils in Relation to Soil Depth Landuse and Landscape Position on Soils of Ikeduru Area of Imo State, Southeastern Nigeria. International Journal of Agric and Rural Development, 20(2): 3132 - 3149.

Rangel-Peraza, JG; Padilla-Gasca, E; López-Corrales, R; Medina, JR; Bustos-Terrones, Y; Amabilis-Sosa, LE; Rodríguez-Mata, AE., Osuna-Enciso, T (2017). Robust soil quality index for tropical soils influenced by agricultural activities. Journal of Agricultural Chemistry and Environment, 6, 199 - 221.

Rajesh, GP; Harshali, HA; Dinesh, PA (2017). Assessment of Soil Nutrients and Physiochemical Parameters in the Region of Hiwarkhed Village of Amravati District (Maharashtra State), India. Rasayan J. Chem, 10(2): 429 - 433.

Raji, B; Malgin, W; Berding, F; Chude, V (2011). Integrate Indegeneous knowledge and soil science approaches to detailed soil survey in kaduna state. Journal of Soil Science and Environmental Management, 2(3): 66 - 73. 
Raw Materials Research and Development Council (RMRDC), (2005). Ginger Survey report of ten Selected Agro Raw Material in Nigeria.

Schoeneberger, P; Wysocki, D; Benham, E; Staff, SS (2012). Field book for describing and sampling soils (Vol. 3). (N. R. Service, Ed.) Lincoln, NE: National Soil Survey Center.

Shivanna, A; Nagendrappa, G (2014). Chemical Analysis of Soil Samples to Evaluate the Soil Fertility Status of Selected Command Areas of Three Tanks in Tiptur Taluk of Karnataka. India Journal of Applied Chemistry, 7(11): 1 - 5.

Sokout, R; Mahdian, M (2011). Spatial variability of macronutrient for soil fertilization management: A case study on Urmia plain. Int. J. Soil Sci., 6(1), 49-59.

Songu, GA; Abu, RD; Temwa, NM; Yiye, ST; Wahab, S; Mohammed, BG (2021). Analysis of Soil Erodibility Factor for Hydrologic Processes in Kereke Watershed, North Central Nigeria. Journal of Applied Science and Environmental Management 25(3): $425-432$.

Suleiman, R; Jimoh, IA; Aliyu, J (2017). Assessment of Soil Physical and Chemical Properties Under Vegetable Cultivation in Abuja Metropolitan Area, Nigeria. Zaria Geographer, 24(1): 89 - 99.

Tale, KS; Ingole, S (2015). A Review on Role of Physico-Chemical Properties in Soil Quality. Chem Sci Rev Lett, 4(13): 57 - 66.

Tel, D; Hagarthy, RE (1984). Mechanical analysis of Soil by the Hydrometer Technique, IITA Training Manual. pg. 7.

Umeri, C; Onymekonwu, R; Moseri, H (2017). Evaluation of physical and chemical properties of some selected soils in mangrove swamp zones of Delta State, Nigeria. Archives of Agriculture and Environmental Science, 2(2): 92-97.

Yahaya, OY; Adamu, GK; Bamidele, OI; Moshood - Oniye, T (2014). The Impact of Cropping Systems on Fertilty Status of Soil in Babanla Rural Area, Nigeria. Academic Research International, 5(4): 181 - 188.

Yakubu, S (2012). Changes in Soil Chemical Properties due to Different Land uses in part of Nigerian Northern Guinea Savanna. Nigerian Geographical Journal, New Series, 8(2): $142-155$. 